\title{
Remoção de hábitos e terapia miofuncional: restabelecimento da deglutição e repouso lingual $* * * *$
}

\author{
Removal of sucking habits and myofunctional therapy: establishing \\ swallowing and tongue rest position
}

Viviane Veroni Degan* (vvdegan@yahoo.com.br)

Regina Maria Puppin-Rontani **

*Fonoaudióloga. Doutora em Odontologia na Área de Fisiologia Oral pela Faculdade de Odontologia de Piracicaba da Universidade de Campinas (Unicamp). Docente do Curso de Mestrado Profissionalizante em Ortodontia e Odontopediatria da Universidade de Araras (Uniararas).

**Cirugiã Dentista. Professora Titular da Área de Odontopediatria da Faculdade de Odontologia de Piracicaba - Unicamp.

***Trabalho Realizado na Faculdade de Odontologia de Piracicaba Unicamp.

Artigo de Pesquisa

Artigo Submetido a Avaliação por Pares

Conflito de Interesse: não

Recebido em 12.04.2004

Revisado em 3.11.2004; 19.03.2005; 21.06.2005; 5.09.2005; 10.11.2005. Aceito para Publicação em 10.11.2005.

\begin{abstract}
Background: the prolonged habit of pacifier sucking and the prolonged use of feeding bottle may cause myofunctional disorder, such as incorrect swallowing pattern and inadequate tongue rest position. Aim: to study the effect of myofunctional therapy (MFT) associated with the removal of the habit of pacifier sucking and the use of feeding bottle (REM) on the rehabilitation of swallowing and tongue rest position. Method: two groups with ten children, ages ranging from four to four years and eight months, who initially presented a pacifier sucking habit and used the feeding bottle were studied. Children on REM group underwent the process of sucking habits removal using the Modified- Counselling Method, whereas children on MFT group underwent the same procedure associated to myofunctional therapy. Pre-treatment assessments were made, as well as 60 and 180 days post-treatment assessments. Data were analyzed using the statistical tests of Mann-Whitney and Wilcoxon $(\mathrm{p}<0.05)$. Results: results indicate that children in the MFT group presented adequate swallowing patterns after 60 and 80 days, and presented adequate tongue rest position after 180 days. Children on the REM group, however, presented adequate swallowing pattern only after 180 days and did not present a significant improvement on the tongue rest position during the assessments. Conclusion: myofunctional therapy associated to the removal of sucking habits presented a better and faster improvement of the swallowing pattern and of the tongue rest position.
\end{abstract} Key Words: Habits; Myofunctional Therapy; Tongue; and Swallowing.

\section{Resumo}

Tema: hábitos prolongados de sucção de chupeta e mamadeira podem provocar distúrbios miofuncionais como o padrão incorreto de deglutição e repouso lingual. Objetivo: estudar os efeitos da associação da Terapia Miofuncional (TMF) e da remoção de hábitos (REM) de sucção na reabilitação da deglutição e repouso lingual. Método: dois grupos composto por dez crianças de quatro anos a quatro anos e oito meses de idade que inicialmente apresentavam hábitos de sucção de chupeta e mamadeira foram estudados. $\mathrm{O}$ grupo denominado REM foi submetido à REM pelo Método de Esclarecimento modificado, enquanto que o grupo denominado TMF também teve os hábitos de sucção removidos pelo mesmo método e foi associada a TMF. Foram realizados exames pré-tratamento, 60 e 180 dias pós-procedimentos. Os dados foram submetidos aos testes estatísticos de Mann-Whitney e Wilcoxon p < 0,05. Resultados: os resultados evidenciaram que o grupo submetido à REM e TMF apresentou adequação dos padrões de deglutição aos 60 dias e 180 dias e correto posicionamento de língua em repouso aos 180 dias, enquanto que o grupo submetido apenas à REM demonstrou adequação do padrão de deglutição apenas aos 180 dias e não apresentou melhora significativa do correto padrão de posicionamento de língua em repouso durante os períodos de avaliação. Conclusão: a TMF associada à REM de sucção de chupeta e mamadeira produziu melhor e mais rápida adequação do padrão de deglutição e de posicionamento lingual em repouso do que apenas a REM de sucção.

Palavras-Chave: Hábitos; Terapia Miofuncional; Língua; Deglutição. 


\section{Introduction}

Continued sucking habit may cause inadequacies on stomatognathic system, due to the misbalance of the forces that naturally take action on oral cavity, (Cayley et al., 2000; Amary et al, 2002, Souza \& Vasconcelos, 2003, Ignacchiti et al, 2003, Degan \& Puppin-Rontani, 2004b, Bertoldi et al., 2005), and may effect malocclusion (Warren et al., 2001; Charchut et al., 2003; Katz, et al. 2004; Emmerich et al, 2004; Bertoldi et al, 2005), which may be concurrently with myofunctional disorders (Tomita et al, 2000; Garreto, 2001; Martinez \& Assêncio-Ferreira, 2001; Zardetto et al., 2002; Felício et al, 2003; Bertoldi et al., 2005).

Children who have continued sucking habit may present anterior open-bite, posterior cross-bite, upper incisor protrusion, diastema, dental impaction, and abnormal abnormal skeletal pattern. In addition, they may have absence of labial seal, inadequate tongue rest position, with protrusion, lower and with bigger dorsal mobility. Functions, such as swallowing may suffer disorders and mouth breathing can be engendered (Garreto, 2001; Degan \& Puppin-Rontani, 2004b).

Studies related to children who have abandoned sucking habit on age from four to six present spontaneous adjustments of the anterior open-bite (Degan etal., 2001; Larsson, 2001; Degan \& PuppinRontani, 2004a; Bertoldi et al., 2005).

However, as pointed by Degan et al. (2001) not all children, who have sucking habit broken, are provided with spontaneous correction and may need to suffer some professional interventional procedure, such as the established of the structures and of the functions of the stomatognathic system, as well as the correct swallowing pattern and the adequate tongueposition during occlusion. The establishing of those functions depends on the equilibrium of oral cavity, which may produce selfcorrection of the anterior open-bite

As a form of restoring the morpho-funcional stability to the oral structures, the myofunctional therapy is considered a treatment procedure that may enhance muscular strength (Pascal et al., 2002). In addition, it causes changes on the functional pattern and prevent deviation of craniofacial development (Haruki, et al., 1999, Jefferson, 2003), since it promotes a new posture of the structures, which are on resting position, and during the use of functions of the stomatognathic system (Degan \& Puppin-Rontani, 2004b).

With the benefit of that, the early intervention on the orofacial musculature dysfunction, which is provided by breaking sucking habits associated to myofunctional therapy, may facilitate the normal craniofacial growth and development (Haruki et al., 1999).

The aim of this study was to verify, by using a clinical evaluation, the influence of myofunctional therapy on tongue resting and swallowing positions, associated with breaking pacifier sucking and nursing bottle-feeding habit, in children aged from 4 to 4 and 8 months years old.

\section{Method}

The present research was developed at Piracicaba Dental School, State University of Campinas - Unicamp, and was approved by its Ethical Committee (\#19/2000). The subject sample was selected just after parental agreement of their child's dental-clinical evaluation. Children aged from 4 to 4.8 years and followed the inclusion criteria had their parents contacted and invited to participate on this research.

Age criteria was determined in a previous study, which pointed out that among children aged 4, 5 and 6 , the four year-old children presented a more effective occlusion correction. (Degan et al., 2001). Parents read and signed the research-agreement term to participate on this study.

The size of the subject sample was determinate by a statistic, from CIAGRI-ESALQ (Informatics Agronomy Centre of the Agronomy School Luís de Queirós)/USP- University of São Paulo. The subject sample included 20 children, who attended kindergarten, from both gender, aged from 4 to 4.8 years, on the beginning of this research. The subject selection followed the criteria: anterior openbite, completed deciduous dentition, no clinical signs of facials obstructive mouth breathing. All children presented the habit of pacifier sucking, which it was freely kept during night and day, and the twice a day nursery bottle-feeding. Patients were randomly distributed in two groups, according to the employed-treatment:

1. REM Group - comprising ten children who were submitted to breaking pacifier sucking and nursery bottle-feeding habits program by Modified- Counselling Method 2. TMF Group - comprising ten children who were submitted to breaking pacifier sucking and nursery bottle-feeding habits by Modified- Counselling Method program and eight sessions of 
myofunctional therapy.

Children who presented anterior and/or posterior cross-bite, obstructive mouth breathing and other sort of sucking habit did not participate on this study. A five year-old child, who kept pacifier sucking and nursery bottle-feeding, was excluded from this study to does not follow the age criterion. A child, who had the deciduous central incisor exfoliated during the research period, attested by the speech and hearing therapist and by the Pediatric Dentist of the Pediatric Dentistry Department, from, Piracicaba Dental School, State University of Campinas, Unicamp was also excluded from this study.

To data collection, an initial interview was conducted for each parent whose child participated on the research.

In order to break sucking habit, the ModifiedCounselling Method (Boni et al., 2001), which was used by Degan et al. (2001), with additional procedures (Degan \& Puppin-Rontani, 2004b), was applied.

After broke sucking habits, children from TMF group were submitted to a thirty-minute, once a week session of myofunctional therapy, during eight weeks, which aimed:

- enhancing muscle strength: superior orbicularis oris muscle, inferior orbicularis oris muscle, buccinator muscle, glossol muscle, which initially were flaccid. These muscles were strengthening by isometric exercises, using a wooden tongue blade, by applying contra-resistance on the muscle or on the focused group of muscle, means lips and tongue; - correcting the following functions of the stomatognathic system: swallowing and nasal breathing. Preparatory swallowing exercises, such as snapping the tongue on the palate and swallowing of liquids and solids food. Stimuli to promote nasal breathing were used; - correcting the structures on resting position. Adequacy of lips position (seal) and adequacy of tongue position (on papilla retroincisal region) During the process to automatic correct resting position, breathing exercises were associated.; - to each volunteer an individual programme was design in order to correct the structures and functions, above related.

For the children on TMF group, pacifier sucking and nursery bottle-feeding breaking was procedure before the orofacial myofunctional therapy.

Results were analysed by clinical exams of the structures and the functionality of the stomatognathic functions, carried out by a speech language pathologist, who were qualified as a research and did not know about the children's included group (Kappa 85\%). For the REM group, exams took place before breaking habits and follow 60 to 180 days after breaking habits date. For the TMF those took place before breaking habit and follow 60 days after breaking habits date and the 8 sessions of myofunctional therapy and after 180 days from that date.

The evaluation criteria were based on a protocol designed by Felício (1999).

A speech and hearing therapist- examiner evaluated tongue during resting position. A 0 (zero) score was attributed to the tongue resting on anterior region of hard palate. Score 1 (one) to tongue, which was resting on mouth ground; and, 2 (two) scores to tongue resting between anterior teeth.

Swallowing was evaluated during the test of water and food swallowing. The observed pattern were classified as adequate (with no active participation of perioral musculature and with labial seal), which was attributed score 0 , and as inadequate (with active participation of perioral musculature and without labial seal), which was attributed score 1 .

\section{Results}

\section{Tongue's Habitual resting Position}

Table 1 shows the percentage distribution regarding the adequate tongue position (score 0 ).

It can be observed that children from the TMF group presented better tongue's positioning at rest, at 180 days $(\mathrm{p}=0.0191)$. Of these children, 50\% presented correction of tongue position in the second evaluation, however the difference was not statistically significant when compared with the first evaluation ( $\mathrm{p}=0.1797)$. The correction of the resting position of the tongue was observed in the third evaluation in relation to the first one $(p=0.018)$. These alterations were significant when compared to the first evaluation, which was not observed in children from REM group who did not present significant difference between the evaluations (initial evaluation/second evaluation $-\mathrm{p}=0.593$, initial evaluation/third evaluation - $\mathrm{p}=0.593$; second evaluation/third evaluation $-\mathrm{p}=1$ ).

It can be observed, on average, that the TMF group presented a significant more adequate swallowing pattern, that is, with less tongue thrust 
and associations of exaggerated movements of perioral muscles. On average, the 60 days and 180 days evaluations did not demonstrate statistically significant difference between them $(\mathrm{p}=0.3173)$, however they statistically differed from the initial evaluation ( $2^{\text {nd }}$ evaluation $-\mathrm{p}=0.018$; evaluation 3 $\mathrm{p}=0.0117$ ). It could be observed that although children from both groups presented similar swallowing profile, only those who underwent myofunctional and broke habits associated presented significant improvement in swallowing patterns. Children from the group that only received the break-habit program presented a similar pattern to the TMF group only in the end of the experiment, after 180 days. Therefore, the treatments association represented, for the studied sample, the fastest improvement in swallowing patterns, that is, correct swallowing patterns in a shorter period of time, however not reaching the levels presented by the TMF group.

\section{Discussion}

The presence of prolonged sucking habits may provoke a lack of balance of natural forces that act upon the oral cavity (Warren et al., 2001; Amary et al, 2002, Souza \& Vasconcelos, 2003, Ignacchiti et al, 2003, Charchut et al., 2003; Degan \& PuppinRontani, 2004b; Bertoldi et al., 2005), being a negative mechanical factor for growth of face, skull and oral structures; they can also promote alterations in the stomatognathic soft-tissue morphology and muscle bahavior patterns, consequently, its functions (Garreto, 2001; Felício et al., 2003; Degan \& Puppin-Rontani, 2004b; Bertoldi et al., 2005).

The Myofunctional Therapy has been efficient as an instrument for the re-arrangement of oral structures by the correction of the shape and functions, acting upon myofunctional disorders, re-establishing functions (Degan \& PuppinRontani, 2004b), correcting muscles force and movements (Pascal et al., 2002), besides assisting the para-functional habits broke and the reestablishment of resting postures (Bacha \& Ríspoli, 1999; Degan \& Puppin-Rontani, 2004b).

The Myofunctional Therapy time of this study was 8 sessions, the same time used by Bacha \& Ríspoli (1999) who conducted the Brief SpeechLanguage Intervention and obtained day breathing and lips posture improvements.

The myofunctional disorders diagnosed ingroup TMF was treated focusing on the patient's individuality. Although the age group and the
TABLE 1. Percentage distribution of children with adequate tongue resting position (score 0 ) in the evaluation periods.

\begin{tabular}{ccc|c} 
& \multicolumn{3}{c}{ Avaliações } \\
\hline & Inicial & 60 Dias & 180 Dias \\
REM & $0 \%$ & $0 \%$ & $0 \%$ \\
TMF & $0 \% *$ & $50 \% * \infty$ & $60 \% * \infty$
\end{tabular}

Legenda: Percentuais seguidos por asterisco (*) na comparação entre grupos (REM e TMF) diferem entre si pelo teste Mann-Whitney $(\mathrm{p}<0,05)$.

Percentuais seguidos por símbolos diferentes sobrescritos $(\$ \infty)$ na comparação dentro do mesmo grupo nos diferentes tempos (inicial, 60 e 180 dias) diferem entre si pelo teste Wilcoxon $(\mathrm{p}<0,05)$.

FIGURE 1. Illustrates the children's score distribution regarding the tongue position during the study time.

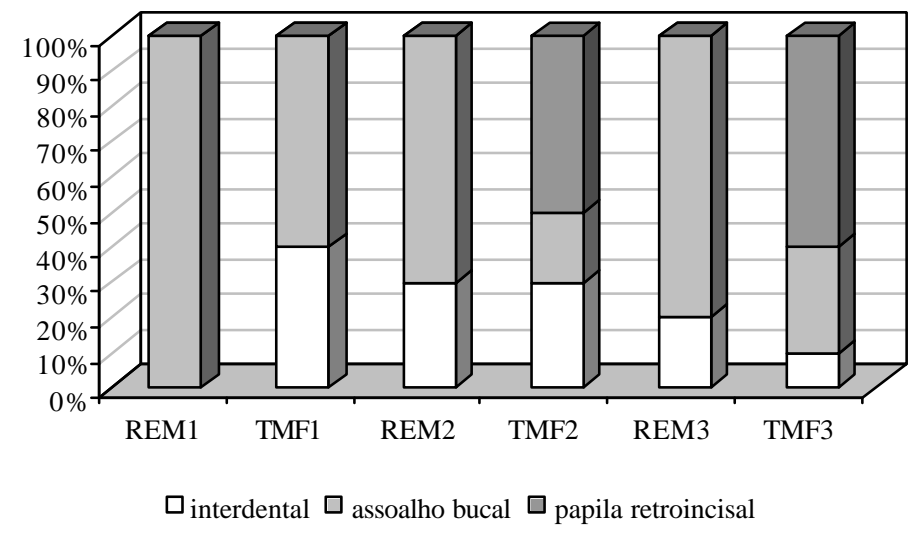

Legenda: TMF1 - grupo TMF período de pré-tratamento; TMF2 - Grupo TMF aos 60 dias; TMF3 - Grupo TMF aos 180 dias; REM1 - Grupo REM período de pré-tratamento; REM2 - Grupo REM aos 60 dias; REM 3 - Grupo REM aos 180 dias.

TABELA 2. Percentage distribution of children with swallowing pattern considered normal (score 0 ), during the evaluation periods.

\begin{tabular}{ccc|c} 
& \multicolumn{3}{c}{ Avaliações } \\
\hline & Inicial & 60 Dias & 180 Dias \\
REM & $0 \%$ & $20 \% *$ & $50 \%^{\infty}$ \\
TMF & $0 \%$ & $70 \%{ }^{\infty}$ & $80 \%^{\infty}$
\end{tabular}

Legenda: Percentuais seguidos por asterisco $(*)$ na comparação entre grupos REM e TMF diferem entre si pelo teste Mann-Whitney ( $\mathrm{p}<0,05)$.

Percentuais seguidos por mesmo símbolo $(\infty)$ na comparação dentro do mesmo grupo nos diferentes tempos (inicial, 60 e 180 dias) não diferem entre si pelo teste Wilcoxon $(p>0,05)$. 
FIGURE 2. Illustrates the scores given to the swallowing pattern presented by the children of the sample during the studied period.

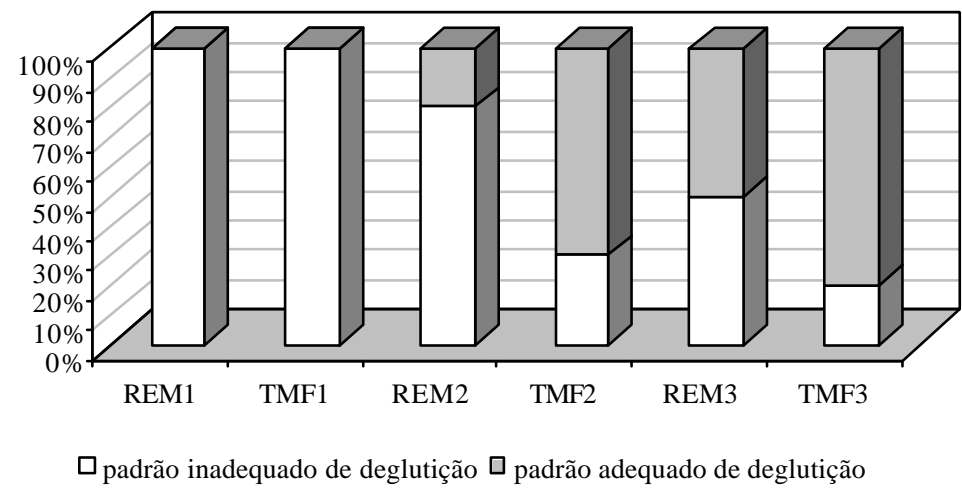

Legenda: TMF1 - grupo TMF período de pré-tratamento; TMF2 - Grupo TMF aos 60 dias; TMF3 - Grupo TMF aos 180 dias; REM1 - Grupo REM período de pré-tratamento; REM2 - Grupo REM aos 60 dias; REM 3 - Grupo REM aos 180 dias. language pathologist and daily exercises practice at home, supervised by the responsible for accompanying the therapies.

Muscle forces, such as the ones provoked by lips and tongue are considered determinants of the vestibule-lingual positioning of the incisors, corroborating the statements of Kotsiomiti \& Kapari (2000) that they would be important for the occlusion stability and stimuli for the adequate growing pattern of maxillas and the face (Warren et al, 2000; Warren et al., 2001; Larsson, 2001; Warren \& Bishara, 2002).

Thus, the Myofunctional Therapy with emphasis on the tongue's adequate resting position would eliminate physical forces and would contribute for the re-arrangement of the oral cavity forces, consequently bringing benefits for the occlusion and for the craniofacial adequate development.

The swallowing pattern presented by the children of REM group showed positive alterations for only $20 \%$ of them at 60 days, and $50 \%$ at 180 days. As for the children of TMF group the swallowing pattern improvement was evident already at 60 days, with $70 \%$ of them presenting adequate swallowing pattern. However, by the end of the experiment, there was no statistical difference between the groups. It can be observed that broke sucking habits were effective for the correction of the swallowing function, however when associated with the Myofunctional Therapy, this correction was faster. The Myofunctional Therapy performed after breaking pacifier and bottle sucking habits was more effective in the correction of the swallowing, confirming the assertions of Benkert (1997). In the beginning of the experiment, the tongue thrust during swallowing was quite evident, as well as the exaggerated perioral muscles contraction, which decreased during the evaluation periods. At the end of the experiment, children presented, in general, absence of tongue thrust, of exaggerated contraction of the facial mimic and presence of labial sealing during swallowing. Although the inadequate swallowing pattern must not be considered an anterior open bite etiology, it must be rehabilitated together with other existing dysfunctions. The simple closing of the anterior open bite may not promote the correct swallowing pattern, as verified by Stormer \& Pancherz (1999) who didn't find electromyographic normalization of the swallowing pattern after the anterior open bite closing.

By the results observed in this research, the early intervention on the orofacial muscles 
dysfunction may re-establish the adequate growing and development potential and the balanced craniofacial development, and, therefore, broke habits and the correction of structures and functions of the stomatognathic system promoted by Myofunctional Therapy are important.

Considering that prolonged sucking habits are common in industrialized populations (Sadakiyo et al., 2003; Degan \& Puppin-Rontani, 2004a) and may cause occlusion alterations, such as the ones detected by Degan et al. (2003) where 63,8\% of the children who were exposed to sucking habits presented some kind of anterior malocclusion, and $57,4 \%$ of them with association of bottle and pacifier sucking, presented anterior open bite. This question could be treated as a public health matter, in accordance with Pereira (1999) who stressed the importance of prevention in speech pathology/ dentistry, aiming at the overall health promotion, specific protection against certain pathology and then, detection, diagnosis and early treatment for minimizing the sequellae through the rehabilitation. In this aspect, the speech pathology could help with breaking sucking habits and the reduction of muscles alteration, functional and occlusal produced by the prolonged maintenance of these habits, informing education professionals such as kindergarten or school teachers, health agents and the children and their families that, many times, don't have access to information, contributing for the adequate global development. Therefore, Myofunctional Therapy, from a public standpoint, may be considered an efficient intervention approach to improve the overall health and well being of the individual (Benkert, 1997).

The early intervention of the orofacial muscles dysfunction may re-establish the adequate growing and development potential and the balanced craniofacial development, and, therefore, the broke of habits and the correction of structures and functions of the stomatognathic system are very important, as observed in this research's results.

\section{Conclusion}

The Myofunctional Therapy associated with breaking pacifier and bottle sucking habits produced better and faster correction of the swallowing pattern and the tongue resting position than only broke mentioned habits. Based on the results and limitations of this study, we recommend the association of Myofunctional Therapy and break sucking habits as a way for the morphofunctional rehabilitation of the swallowing patterns and tongue resting position. 


\section{References}

AMARY, I. C. M.; ROSSI, L. A. F.; YUMOTO, V. A.; FERREIRA, V. J. A.; Marchesan, I. Q. Hábitos deletérios x alterações de oclusão. Revista CEFAC - Atualização Científica em Fonoaudiologia, São Paulo, v. 4, n. 2, p. 123-126, maio-ago. 2002.

BACHA, S. M. C.; RÍSPOLI, C. M., Myofunctional therapy: brief intervention. Int. J. Orofacial Myology, Seattle, v. 25, p. 37-47, 1999.

BENKERT, K. The effectiveness orofacial myofuntional therapy in improving dental occlusion. Int. J. Orofacial Myology, Seattle, v. 23, p. 35-46, nov. 1997.

BERTOLDI, P.; FELÍCIO, M.; MATSUMOTO, M. A. Effect of the early intervention of oral habits on the development of dental occlusion Pró-Fono Revista de Atualização Científica, Barueri, v. 17, n. 1, p. 37-44, jan-apr. 2005.

BONI R. C.; ALMEIDA, R. C.; DEGAN, V. V. Utilização do método de esclarecimento para remoção do hábito de sucção de chupeta e/ou mamadeira. J. Orthop-Orthod Pediatr. Dent., v. 2, n. 11, p. 16, 2001.

CAYLEY, A. S.; TINDALL, A. P.; SAMPSON, W. J.; BUTCHER, A. R. Electropalatographic and cephalometric assessment of myofunctional therapyin open-bite subjects. Orthod. J., Brisbane, v. 16, n. 1, p. 23-33, mar. 2000.

CHARCHUT, S. W.; ALLRED, E. N.; NEEDLEMAN, H. $\mathrm{L}$. The effects of infant feeding patterns on the occlusion of the primary dentition. J. Dent. Child, Chicago, v. 70, n. 3, p. 197-203, sep-dec. 2003.

DEGAN, V. V.; BONI, R. C.; ALMEIDA, R. C. Idade adequada para remoção de chupeta e/ou mamadeira, na faixa etária de 4 a 6 anos. J. Orthop-Orthod Pediatr. Dent., v. 3 , p. 5-16, 2001.

DEGAN, V. V.; PUPPIN-RONTANI, R. M. Prevalence of pacifier-sucking habits and successful methods to eliminate them-a preliminary study. J. Dent. Child, Chicago, v. 71, n. 2, p. 148-151. may-aug 2004a.

DEGAN, V. V.; PUPPIN-RONTANI, R. M. Terapia Miofuncional e hábitos orais infantis. Revista CEFAC Atualização Científica em Fonoaudiologia, São Paulo, v. 6, n. 4, p. 396-404, out.-dez. 2004b.

DEGAN, V. V.; SADAKYIO, C. A.; PUPPIN-RONTANI, R. M.; PIGNATARO NETO, G. Study of the relationship between the anterior malocclusion and sucking habits in children aged 42 to 83 months. In: ANNUAL MEETING OF AMERICAN ASSOCIATION OF DENTAL RESEARCH, 32.; ANNUAL MEETING OF CANADIAN ASSOCIATION FOR DENTAL RESEARCH, 27., 2003, San Antonio, Texas. Anais eletrônicos. Disponível em: <http://iadr.confex.com/iadr/2003SanAnton/ abstract_27509.htm> Acesso em: 10 out. 2005.

EMMERICH, A.; FONSECA, L.; ELIAS, A. M. DE.; MEDEIROS, U. V. The relationship between oral habits, oronasopharyngeal alterations, and malocclusion in preschool children in Vitoria, Espirito Santo, Brazil. Cad. Saude Publica, v. 20, n. 3, p. 689-697, may-jun. 2004.

FELÍCIO, C. M. Fonoaudiologia aplicada a casos odontológicos: motricidade oral e audiologia. São Paulo: Pancast, 1999. p. 174-175.

FELÍCIO, C. M.; FERREIRA-JERONYMO, R. R.;
FERRIOLLI, B. H. V. M.; FREITAS, R. L. R. G. Análise da associação entre sucção, condições miofuncionais orais e fala. Pró-Fono Revista de Atualização Científica, Barueri, v. 15, n. 1, p. 31-40, 2003.

GARRETO, A. L. Orofacial myofunctional disorders related to malocclusion. Internacional Journal of Orofacial Myology, v. 27, p. 44-54, nov. 2001.

HARUKI, T.; KISHI, K.; ZIMMERMAN, J. The importance of orofacial myofunctional therapy in pediatrtic dentistry: Reports of two cases. J. Dent. Child., v. 84, n. 8 , p. 103-109, 1999.

IGNACCHITI, P. R.; GESUALDI, K. C.; CURSAGE, F. P. C.; ALMADA, R. O. Hábito de sucção de chupeta e mordida aberta anterior na criança com dentição decídua. Revista CEFAC - Atualização Científica em Fonoaudiologia, São Paulo. v. 5, n. 3, p. 241-245, jul.-set. 2003.

JEFFERSON, Y. Orthodontic diagnosis in young children: beyond dental malocclusions. Gen Dent. v. 51, n. 2, p. 104-111, mar.-apr. 2003.

KATZ, C. R., ROSENBLATT, A.; GONDIM, P. P. Nonnutritive sucking habits in Brazilian children: effects on deciduous dentition and relationship with facial morphology. Am. J. Orthod. Dentofacial Orthop., v. 126, n. 1, p. 53-57, jul. 2004.

KOTSIOMITI, E.; KAPARI, D. Resting tongue position and its relation to the state of the dentition: a pilot study. J. Oral. Rehabil., v. 27, n. 4, p. 349-354, apr. 2000.

LARSSON, E. Sucking chewing and feeding habits and the development of crossbite: a longitudinal study of girls from birth to 3 years of age. Angle Orthod., Appleton, v. 71, n. 2, p. 116-119, apr. 2001.

MARTINEZ, M. I.; ASSÊNCIO-FERREIRA, V. J. Hábito orais viciosos versus alterações de oclusão dentária: prevalência de crianças com oclusão normal e hábitos orais viciosos. Revista CEFAC - Atualização Científica em Fonoaudiologia, São Paulo. v. 3, n. 2, p. 127-131, jul.dez. 2001.

PASCAL, H. H. M.; VAN LIESHOUT, P. H.; BOSE, A.; NAMASIVAYAM, A. K. Physiological effects of an 8-week mechanically aided resistance facial exercise program. Int J. Orofacial Myology., v. 28. p. 49-73, nov. 2002.

PEREIRA, M. T. J. G. Uma vivência em saúde pública. (Monografia) - CEFAC, São Paulo. Disponível em: <http:/ /www.cefac.br/teses.php> Acesso: 12 dez. 2003.

SADAKIYO, C. A.; DEGAN, V. V.; RONTANI, R. M. P. Prevalência de hábitos de sucção e sucesso de métodos usados na remoção em crianças de 0 a 6 anos de idade. Pesquisa Odontológica Brasileira - Brazilian Oral Research, v. 17, p. $89,2003$.

SOUZA, N. B.; VASCONCELOS, T. C. A. Influência de hábitos orais como fator etiológico de mordida aberta anterior. Revista CEFAC - Atualização Científica em Fonoaudiologia, São Paulo, v. 5, n. 3, p. 235-240, jul.-set. 2003.

STORMER, K.; PANCHERZ, H. Electromyography of the perioral and masticatory muscles in orthodontic patients with atypical swallowing. J. Orofac. Orthop, v. 60, n. 1, p. 13-23, 1999. 
TOMITA, N. E.; BIJELLA, V. T.; FRANCO, L. J. Relação entre hábitos bucais e má oclusão em pré escolares. Rev. Saúde Pública, São Paulo, v. 34, n. 3, p. 299-303, jun. 2000.

ZARDETTO, C. G.; RODRIGUES, C. R.; STEFANI, F. M. Effects of different pacifiers on the primary dentition and oral myofunctional strutures of preschool children. Pediatr. Dent., v. 24, n. 6, p. 552-560, nov.-dec. 2002.

WARREN, J. J.; BISHARA, S. E. Duration of nutritive and nonnutritive sucking behaviors and their effects on the dental arches in the primary dentition. Am. J. Orthod. Dentofacial Orthop., St. Louis, v. 121, n. 4, p. 347-356, apr. 2002.

WARREN, J. J.; BISHARA, S. E.; STEINBOCK K. L.; YONEZU T.; NOWAK, A. J. Effects of oral habits' duration on dental characteristics in the primary dentition. J. Am. Dent. Assoc., v. 132, n. 12, p. 1685-1693, dec. 2001.

WARREN, J. J.; LEVY, S. M.; NOWAK, A. J; TANG, S. Non nutritive sucking behaviors in preschool children: a longitudinal study. Pediatr. Dent., Chicago, v. 22, n. 3, p. 187-191, may-jun. 2000. 